\title{
Globalization and Development in Contemporary India: Cultural Perspective
}

\author{
Shobhit Srivastava \& Altamash Khan \\ ${ }^{1}$ Centre for Globalization and Development Studies \\ ${ }^{2}$ University of Allahabad, Allahabad \\ Correspondence: Shobhit Srivastava, Centre for Globalization and Development Studies.
}

Received: January 6, 2016

doi:10.11114/ijsss.v4i3.1375
Accepted: January 18, 2016

Available online: February 11, 2016

URL: http://dx.doi.org/10.11114/ijsss.v4i3.1375

\begin{abstract}
It is fair to say that the impact of globalization in the cultural sphere has most generally been viewed in a pessimistic light. Typically, it has been associated with the destruction of cultural identities, victims of the accelerating encroachment of a homogenized, westernized, consumer culture. The contemporary phase of globalization which began in the post-cold war era i.e.in 90's, when in 1991 govt. of India followed the policy of LPG (Liberalization, privatization and globalization). Ever since then there have been numerous changes in various areas i.e. political, social and economical. Here in we will focus on social arena which largely includes the following: (i) Culture which can be in present scenario be termed as global cultural diversity, (ii) Education and health sector affected by SAP (Structural adjustment programme), (iii) Social institution i.e. family, marriage and kinship, (iii) Bazaar culture. Here in, we will be critically analyzing the above mentioned aspects and will examine how globalization is transforming the Indian society.
\end{abstract}

Keywords: globalization, global culture, SAP, westernization and social institutions.

\section{Introduction}

As we are in the contemporary phase of globalization, which has impacted many sphere and culture too is one of them. A culture is a way of life of a group of people--the behaviors, beliefs, values, and symbols that they accept, generally without thinking about them, and that are passed along by communication and imitation from one generation to the next (Griswold, 2012: long, 1997).With the advent of globalization changes have occurred in culture due to increased transparency of other cultures of the world i.e. like westernization has largely encroach the Indian culture because of increased interconnectedness which too is an effect of globalization. This interconnectedness has been catalyzed by internet, social networking sites (face-book, twitter, what's-app, instagram etc), television; mobile phones etc. This change in culture has actually transformed the only concept of culture, i.e. the coming of global culture.

In 1991 when Indian economy was under crisis Indian government was granted loan by IMF and WB, after which SAP (structural adjustment programme) arrived in the policy of Indian economy. This had a worse effect on social sector (Health and Education) and lowered the standard of living.

Globalization has too transformed the only concept of social institutions in Indian scenario i.e. like that of family, firstly there were joint families, then those changed into nuclear one and in today's era the very concept has changed. Changes have also occurred in how one see's marriage and kinship.

With the advent of globalization the relationship between the traditional costumer and shopkeeper has been whitewashed, and here comes the new relation between the costumers and e-shopkeepers. This has transformed the very concept of Bazaar culture.

So, globalization has affected the above listed aspects and has both positive and negative consequences. Here in globalization is like "Juggernaut" (Anthony Giddens, 1990), engine which is unstoppable and has no direction, sometimes it threatens to rush out of our control and crush those who used resist it.

\section{Literature Review}

Some earlier work has been done in this field, like that of Shobha Pais, Globalization and its Impact on Families (2006). In her paper she talked about psychological impact of globalization on family, and then she moved on to the 
socio-cultural impact of globalization on families largely on women and children and how technology epically T.V has effected in this field. She has talked about how technology has made status of women better than before like computer and internet. At last she too asked the question that whether Globalization is making poor poorer?

John Tomlinson in his article 'globalization and cultural identity' has talked about a pessimistic impact of Globalization on culture although he says that at times globalization is often associated with the distructution of cultural identities, victims of the accelerating encroachment of a homogenized, westernized, consumer culture, he does not denies these impacts but gives another perspective about cultural globalization. He equates cultural identity as a product of globalization i.e. globalization has led to the emergence of a new cultural identity. He also talked about globalization of capitalism which also is an important dimension in understanding the changes in the cultural identities. He also talked about deterritorialitization i.e. the social geographical location have become irrelevant in the age of globalization.

J.Boli and F. J. Lechner in their paper 'Globalization and world culture', talked about the upcoming of globalization and emergence of a world culture. According to them Globalization involves expanding worldwide flows of material objects and symbols, and the proliferation of organizations and institutions of global reach that structure those flows. They also talked about the role of transnational organization and various other non-state actors (NGO's INGO's) Civil Societies etc I framing the world culture.

According to them the world culture is dominated by the powerful Western Europe i.e. anglo-european culture. According to him World culture is not only a homogenizing force as it also engenders and supports diversity and differentiation. Five factors are very important for understanding world culture promotion of heterogeneity, they are:-1. Success for the nation state political form; 2. Cultural relativism and the ideology of cultural authencity; 3. Regionalism; 4.consumerism as adaptive interpretation; 4.creolization.

He too talked about dimensions of world culture i.e. expressive and normative dimension. Expressive dimensions include clothing, fashion, food etc, where as normative dimension include individualism, human rights etc. He talked about globalization and cultural conflict in which he says that how western countries have dominated the international or say global economy and international organizations too are being governed by western countries only. This has led to conflict between the west and non- western countries and less developed countries have asked for New International economic order. According to them religion too play a very important role in global culture.

Here in my paper is purely on that how various elements of globalization has impacted the culture in Indian scenario.

\section{Methodology}

The paper content largely based on secondary data i.e. from research journals, research papers, and books.

\subsection{Development, Globalization, and Culture}

At a very basic level development can be understood as a process of transformation from point A to point $\mathrm{B}$, where $\mathrm{B}$ is much more advanced than A in terms of e.g. technology, infrastructure, economy, human recourse etc. In the process of development it has stratified the entire globe where in some countries, communities and people have become superior and globalized while some sections are being excluded, which has led to the marginalization and deprivation of certain nations and sections of the globalized world.

Globalization is a process of increased interconnectedness and mutual interdependence between nations and people all over the world, in this process every nation and its citizens get affected by the events and happenings in other nations and it's a live process. Globalization is very much catalyzed by technological innovations like internet, easy and cheap transportation, mass media etc.

The concept of globalization has been explained at four levels:-

1. Economic dimension.

2. Political dimension.

3. Communication

4. Socio-cultural dimension.

At a very basic level culture is something that designs/ frames human life or is the way of life. It the driving force of human civilization. In earlier times culture was a static process but with the advent of globalization it has become a dynamic process i.e. People share their culture as well as inculcate some desirable changes. This cultural change has led to the emergence of concepts like global culture. These three processes i.e. Development, globalization and cultural change are interdependent on each-other. With technological development came globalization and with the advent of globalization came the cultural change. 

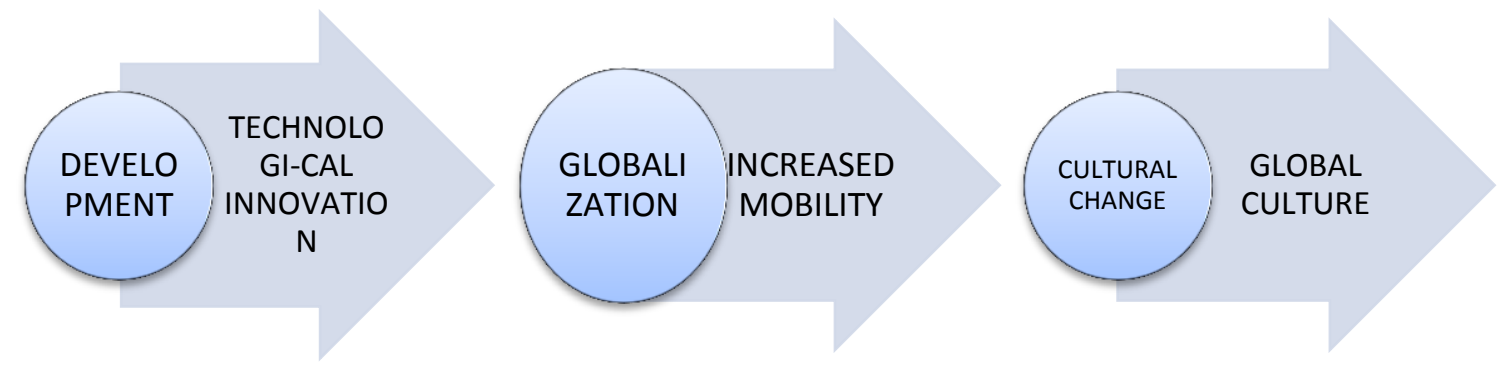

\subsection{Cultural Globalization}

Cultural globalization refers to the transmission of ideas, meanings and values around the world in such a way as to extend and intensify social relations. This process is marked by the common consumption of cultures that have been diffused by the Internet, popular culture media, and international travel. Cultural globalization involves the formation of shared norms and knowledge with which people associate their individual and collective cultural identities. It brings increasing interconnectedness among different populations and cultures.

With the advent of cultural globalization the process of homogenization and hybridization have emerged. Firstly, talking about homogenization it could be seen as the emergence of a common culture. Here in we could see the dominance of American or the Western culture e.g. Mc donaldization, coco-colonization etc. Secondly the concept of hybridization refers to the interrelation and interaction of different cultures wherein a local culture becomes popular and global and accepted by a majority. E.g. the coming of TATTOOS which was the culture of local tribes in Africa has become so very popular all over the world in very recent past.

\subsection{Bazaar Culture}

Earlier people especially women used to shop the household commodities (grocery, fashion etc) by going to the particular shop. The shop from which commodities were purchased was like family shop (like family doctor). This culture is termed as bazaar culture.

In the era of globalization, big shopping malls, wall marts, complexes etc have engulfed the whole market. The main advantage of these malls are that one can buy everything under one roof like vegetables, fruits, grocery and everything needed in everyday use. People are attracted towards malls because:-

1. All under one roof

2. Excellent parking and other facilities

3. Air conditioned area

4. Attractive offers

5. Many cash counters

This has given to the rise of new culture called mall culture. This mall culture is becoming more successful because of introduction of McDonald, Dominos, and pizza hut within the complex and cinema halls like PVR.

But this mall culture is now being overtaken by e-shopping. With the rapid spread of internet users the e-shopping sites like Flipkart.com, snapdeal.com, bigbasket.com and many more are becoming Giant shopping hubs. The main advantages of these e-shopping hubs are:-

1. Shop from home

2. Save plenty of time

3. Fast delivery and return policy too cheap, save time and

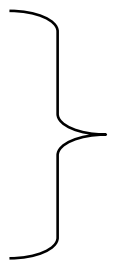

saving of time and money. 
4. Cash on delivery or can shop by debit or credit card money.

5. Consumer friendly policies

\subsection{Sap (Structural Adjustment Programmes)}

Structural adjustment programmes (SAPs) consist of loans provided by the International Monetary Fund (IMF) and the World Bank (WB) to countries that experienced economic crises. SAPs are supposed to allow the economies of the developing countries to become more market oriented and this then forces them to concentrate more on trade and production so it can boost their economy and due to this, these programmes have been criticized because of their effects on the social sector. It was in the 90,s that the policies of LPG were adopted by Indian govt. as a means to tackle the economic crises which was faced by the nation during that period. The main focus of these programmes was to change the status of the nation state from a welfare state to profit oriented state, as a result the state was asked to remove all kinds of subsidies and other benefits which were provided to the citizens. These policies largely affected the social institutions i.e., areas of health and education. Herein, one can notice that the standards of hospitals and educational institutions which were run by the government were not up to the mark. Women were negatively affected by privatization and trade liberalization policies in a number of sectors such as handlooms, jute, cotton, food and beverage, etc. They either lost their jobs or were affected by job losses of their spouses. A total of 89,971 workers (men and women) lost their jobs in the state owned enterprises (SOEs) till June, 1997. PRA findings also show that women losing their jobs find fewer alternative employment opportunities. Structural adjustment policies are likely to negatively affect the employment position of women. These policies mainly affected those sectors where women were concentrated like: social, personal and community services, finance, real estate and business services. Secondly, the public sector which was an employer of the last past was having very few new jobs during structural adjustment period. Women were likely to be affected because of their low levels of education. Thirdly, women also joined the informal sector in large numbers due to the retrenchment arid liberalization policies. Policymakers faced the challenge of creating policies addressing the issue of effects of structural adjustment policies on women's. This is important given the role women play in development.

\section{Effect of Globalization on Social Institution I.E. Family, Marriage and Kinship}

Globalization as we all know has no Lakshman-rekha and hence has its effect beyond every boundary i.e. in every sphere which includes social, economic and political sphere. It is showing adverse effect on social institutions as well i.e. on family, marriage and kinship.

Family the most important social institution has gone under adverse change in its structure. Earlier there were joint families, which lately changed to nuclear family. Till nuclear family, the very concept of family was safe but with the coming of globalization changes took place and the concept of family changed. In 1949, George Peter Murdock defined the family as "a social group characterized by common residence, economic cooperation, and reproduction." He added that the family "includes adults of both sexes, at least two of whom maintain a socially approved sexual relationship, and one or more children". Thus we see that family as defined by Murdock constitutes of a husband, wife, children but in the present scenario we see that one of the characteristic of family i.e. 'common residence' has eventually transformed ,currently we see husband works somewhere else; wife lives somewhere else; and may be children lives and study somewhere else. So globalization has scattered them all and has brought about change in family structure. 
Industrial revolution has brought about specialized division of labor and also it has induced sexual division of labor. Earlier both men and women were involved in economical work to earn for their family but with the coming of industrial revolution women were limited as housewives ( child care and rear, household works i.e. care economy ), but now in industrial and modern society or post-industrial or post-modern society the family has become highly unstable, because of high work load, increased hours of working which results in, men giving less time to their families and this has caused in the increased cases of family disputes which at times lead to divorce.

This globalization in the same way has made some changes in marriage rule too. With globalization and spreading of family individuals children are now not answerable, they are more independent and take all decisions on their own. Earlier there was more arranged marriage in which caste, gotra, family status etc were given very much priority but in modern or post-modern society these are irrelevant issues for present generation. Both girl and boy are so much independent that they during marriage they give no importance to caste, gotra and even religion some times. E.g. Even Hindu marries a Muslim or Sikh or Christian.

With the upcoming of ICT i.e. T.V, internet, mobile phones etc which can be seen as a product of modern globalization has also to a certain extent has contributed to the changes taking place in the social institutions, by this we mean that people have become more self centered / oriented. There has been a change that has occurred within family, members in-spite of sharing a common residence hardly interacts with each other. Earlier, where people used to interact and have entertainment among them but with the coming of ICT preferences have changed, internet, T.V and mobile have got an upper-hand over family gatherings which in a way have led to the alienation of family members among themselves.

\section{Conclusion}

Development as we see is a multidimensional phenomenon which has several aspects. The process of development dates back to very existence of human society i.e. Paleolithic from where the society transformed to different stages and reached the post-modern society. Here one of the major developments which saw a major transformation in the lives of human was the industrial revolution. This revolution can't just be linked with the emergence of an industrial society, industries technologies but there were various socio-cultural impacts which largely need to be focused. Scholars like Marx, Durkheim, and Parson have talked about these impacts in their writings. Industrial revolution brought about a change in a family structure and as Durkheim talked about division of labor which further in the era of globalization changed the very definition of family. The concept like alienation also shows the socio cultural changes taking place and social institutions getting affected. These changes which were a bit blur during the post-industrial period became very much visible with the advent of globalization.

With the emergence of Breton-wood institutions i.e. World Bank, International Monitory fund etc there the concept of economic globalization intensified at the global level. This economic globalization forced various developing nations to adopt structural development policies, which directly had a visible effect on the social sectors like education and health sector. Later on in 1990's with the Government of India opting the policies of LPG and the economic crisis of 90's forced the Government of India to adopt SAP which largely effect social sector and also intensified the gender disparity further. Expenditure on social sector was cut down which largely effected the marginalized section. So there is a need that every policy adopted by govt. should be filtered in such a way that marginalized section should not be negatively affected by it, for this grass root planning's and research techniques like PRA (participatory rural appraisal) should be implemented.

According To Anthony Giddens, Globalization is like rath of "jaggannath" which is unstoppable and who so ever comes its path it crushes it down. With the coming of globalization we saw the change in the structure of social institutions and these changes cannot be altered but its effect can be reduced to some extent.

Thus we can say that one need not be extremist or judgmental about the impacts of globalization rather a self assessment of these impacts should be made. The idea of universal impact should be discarded and therefore the view point that it crushes those who comes in the way of globalization, should be transformed and it should be seen as an engine controlled by humans and they should be the one deciding whether they want to ride the engine or not.

\section{References}

Appadurai, A. (1996). Modernity at Large: Cultural Dimensions of Globalization." University of Minnesota Press, Minneapolis, MN.

Boli J., \& Thomas, G. M. (eds.) (1999). “Constructing World Culture: International Nongo.ernmental Organizations Since” 1875. Stanford University Press, Stanford, CA

Featherstone, M., \& Lash, S. (1999). Spaces of culture. London. SAGE publications.

Giddens, A. (1990). The Consequences of Modernity, Cambridge: polity, 1990. 
Hall, P. Cities in civilization; culture, Innovation and Urban Order, Weindenfeld and Nicholson, London.

Hirst, P., \& Thompson, G. (2003). The Limits to Economics Globalization, in: Held, David and Anthony McGrew. The Global Transformations Reader: An Introduction to the Globalization Debate, Polity.

Pais, Shobha. (2006). "Globalization and its impact on families".

Robertson, R. (1988). “The Sociological Significance of Culture: Some General Considerations”, Theory, Culture \& Society, 5, 3-23.

Robertson, R. (1992). “Globalization: Social Theory and Global Culture”. Sage, London

Sotshangane, N. (2002). "What Impact Globalization Has on Cultural Diversity", Alternatives: Turkish Journal of International Relations, 1(4), 214-229. Acta academia, Bloemfontein: Publication Office, UOFS-SASOL Library. Waters, M. (1995). Globalization, London and New York: Routledge.

Thomas, G. M., Meyer, J. W., Ramirez, F. O., \& Boli, J. (1987). “ Institutional Structure: Constituting State, Society, and the Ind vidual." Sage, Newbury Park, CA.

Weber, Max, (1930). “The Protestant Ethic And The Spirit of Capitalism”, Allen and Unwin, London.

\section{(cc) $\mathrm{BY}$}

This work is licensed under a Creative Commons Attribution 3.0 License. 